Article

\title{
Organic Petrographical Features of Fly Ashes Originating from Coal and Coal-SRF Co-Combustion
}

\author{
Małgorzata Wojtaszek $^{1}$ (D), Ryszard Wasielewski ${ }^{1}$ and Stavros Kalaitzidis ${ }^{2, *(\mathbb{D})}$ \\ 1 Institute for Chemical Processing of Coal, 1 Zamkowa Street, 41-803 Zabrze, Poland; \\ mwojtaszek@ichpw.pl (M.W.); rwasielewski@ichpw.pl (R.W.) \\ 2 Department of Geology, University of Patras, 26504 Patras, Greece \\ * Correspondence: skalait@upatras.gr; Tel.: +30-2610996158
}

Citation: Wojtaszek, M.;

Wasielewski, R.; Kalaitzidis, S. Organic Petrographical Features of Fly Ashes Originating from Coal and Coal-SRF Co-Combustion. Minerals 2021, 11, 128. https://doi.org/ $10.3390 / \min 11020128$

Academic Editor: Shifeng Dai Received: 28 December 2020 Accepted: 26 January 2021 Published: 28 January 2021

Publisher's Note: MDPI stays neutral with regard to jurisdictional claims in published maps and institutional affiliations.

Copyright: (c) 2021 by the authors. Licensee MDPI, Basel, Switzerland. This article is an open access article distributed under the terms and conditions of the Creative Commons Attribution (CC BY) license (https:/ / creativecommons.org/licenses/by/ $4.0 /)$.

\begin{abstract}
In this study, the features of fly ashes originating from industrial-scale high volatile bituminous coal combustion and co-combustion of coal with $10 \%$ admixture of alternative fuel SRF (solid recovered fuel) are presented, with emphasis on the organic petrographical characteristics. The organic petrographical and mineralogical data are co-evaluated with geochemical data, with the aim to provide a full classification of the studied fly ashes, as well as base information toward any potential application of this waste material, according to the recycling economy principles. By applying organic petrographical methods, the assignment of the carbon-rich residuals to the respective feed fuel, either coal or SRF, can be achieved. The obtained quantitative evaluation provides useful information regarding the combustion conditions in the stoker boiler. The analyzed fly ashes contain significant C-residuals, mostly in the form of fused, dense, and anisotropic particles, while the enrichment in sooty particles is caused due to the addition of SRF fuel. In conjunction with the moderate-low content of potential hazardous elements, the features of the contained Cresidual phases suggest that these fly ashes could possibly be the subject of further studies for their applicability as soil improvements.
\end{abstract}

Keywords: alternative fuel; coal co-combustion; fly ash; organic petrography

\section{Introduction}

Fly ashes are dusty materials collected from flue gas that usually exhibit very uniform grain distribution, comprised mainly by an amorphous and crystalline inorganic fraction and unburned carbon-rich particles (C-residues), e.g., [1-4]. Most of the countries that utilize coal for power production face the problem of managing the large quantities of fly ashes that are annually produced. Apart from the obvious solution of burying fly ashes into the depleted excavations during rehab, a significant industrial stream has also been developed within the last decades to utilize this material in various applications, hence contributing toward recycling solutions. The most prominent utilization of fly ashes is as a geopolymer and a cement additive in the construction sector due to certain pozzolanic properties the Si-Al-rich fly ashes exhibit, e.g., [5-8]. However, a significant amount of research has also been conducted regarding the application of fly ashes in replacing other materials in the fields of agricultural soils bio-amelioration and industrial wastes treatment in an effort to reduce the environmental footprint of coal utilization, e.g., [9-11]. Depending on the properties of the fly ashes, these wastes can be utilized in different fields.

In recent years, Poland has been the largest coal producer in Europe [12]. In summer of 2020 Poland also overtook Germany for the first time, in terms of coal usage, as the country relies on coal to provide $74 \%$ of the country's electricity. As a result, about $4.2 \mathrm{Mt}$ of fly ash is produced annually from the combustion of fossil fuels and/or co-combustion with biomass, with only a small part $(<10 \%)$ of this fly ash being transferred to the recycling process, particularly in the construction sector [13-15]. 
The commercial application of fly ash in Poland is limited and dependent on the quality parameters that are regulated by strict standards, since adverse effects can easily be encountered. The physical and chemical properties of fly ash depend primarily on the type of combusted fuel, as well as on the applied combustion technology, e.g., [16-18].

The organic petrological studies of fly ashes have been proven to be very valuable in visualizing the various particles, hence identifying the origin and industrial processes that affect the combusted materials, e.g., [19,20]. In this study, the organic petrographical features following the recently established ICCP Classification published by Suárez-Ruiz et al. [21], as well as the mineralogical characteristics of two fly ash samples, are presented. Fly ashes were obtained from industrial-scale coal combustion and coal blended with alternative fuel (i.e., solid recovered fuel from a municipal waste-sorting installation) cocombustion. The petrographical and mineralogical data are co-evaluated with geochemical data, with the aim to provide a full classification of the studied fly ashes, as well as base information toward any potential application of this waste material, according to the recycling economy principles, e.g., [22].

\section{Materials and Methods}

Industrial research of the coal co-combustion for this study was conducted in boiler installation of District Heating Facility in Racibórz, Poland. Two fly ash (FA) samples from stoker boiler were investigated in this study, one representing byproduct of a typical (high-volatile bituminous rank, $\mathrm{VR}_{\mathrm{o}}: 0.81 \%$ ) Polish thermal hard coal combustion $\left(\mathrm{FA}_{\mathrm{HC}}\right)$ and the second representing a co-combustion of coal with $10 \%$ admixture of alternative fuel $\left(\mathrm{FA}_{\mathrm{SRF}}\right.$ ) that came from a municipal waste-sorting installation (Table 1). The raw SRF (solid recovered fuel) is a commercial product in the form of briquettes of compacted material. Raw SRF is a mixture of mainly (up to 60\%) plastics and biomass, with the remaining $40 \%$ comprising cellulose-based industrial products, fabric, and rubber [23]. The boiler type WR-25, manufactured by SEFAKO S.A. (Sędziszów, Poland), was used in the test, constituting a high-temperature water tube boiler with travelling grate and forced draught. The boiler is equipped with a single-step fly ash precipitation system, which consists of cyclone batteries. Samples of fly ash were collected every $60 \mathrm{~min}$ from the hopper of cyclones dedusting equipment.

Table 1. Properties of the feed fuels used in this study (after Wasielewski et al., [23]) (VM: Volatile matter, C: Carbon, S: Sulfur).

\begin{tabular}{|c|c|c|c|c|c|}
\hline Fuel & Moisture & Ash & VM & $\mathrm{C}$ & S \\
\hline & wt. $\%$-ar ${ }^{1}$ & wt. $\%-d b^{2}$ & wt. $\%$-daf ${ }^{3}$ & wt. $\%-d b^{2}$ & wt. $\%-\mathrm{db}^{2}$ \\
\hline Hard coal & 5.3 & 23.9 & 32.9 & 65.5 & 0.52 \\
\hline Blend of coal and $10 \%$ SRF & 7.2 & 20.9 & 45.5 & 64.9 & 0.44 \\
\hline
\end{tabular}

${ }^{1}$ ar: As-received basis; ${ }^{2}$ db: Dry basis; ${ }^{3}$ daf: Dry ash-free basis.

Petrographical examination was conducted with the aid of an AxioImager M1m polarizing microscope (Carl Zeiss, Oberkochen, Germany), under polarized reflected light in the presence of Lambda plate, using an oil immersion objective and magnification of $500 \times$ following the guidelines of International Committee for Coal and Organic Petrology (ICCP) for organic matter [24]. Characterization and quantification of the fly ash components followed the nomenclature and guidelines established by ICCP [21]. The terminology of inorganic particles followed the terms proposed by Valentim et al. [3].

Mineralogical analysis was carried out using a Bruker D8 Advance X-ray diffractometer (Bruker, Billerica, MA, USA) equipped with a LynxEye ${ }^{\circledR}$ detector. The scanning area covered the interval $2 \theta 4-70^{\circ}$, with a scanning angle step of $0.015^{\circ}$ and a timestep of $1 \mathrm{~s}$. Mineral identification and quantification were achieved using $\mathrm{EVA}^{\circledR}$ (v.12.0, Bruker, Billerica, MA, USA) and Rietveld-based TOPAS ${ }^{\circledR}$ software (v.3.0, Bruker, Billerica, MA, USA), respectively. 
The petrographical and mineralogical data were co-evaluated with the physical and geochemical properties of the studied samples, which were published previously [23].

\section{Results and Discussion}

\subsection{Inorganic Geochemical and Mineralogical and Features}

A notable feature of both fly ashes is the significant amount of un-combusted organic fraction, accounting for $29 \%$ and $33 \%$ for the $\mathrm{FA}_{(\mathrm{HC})}$ and $\mathrm{FA}_{(\mathrm{SRF})}$, respectively (Table 2$)$. In terms of major oxides, $\mathrm{SiO}_{2}$ and $\mathrm{Al}_{2} \mathrm{O}_{3}$ are the prevailing oxides for both samples, with the $\mathrm{Si}-\mathrm{Al}$ fraction exceeding $65 \%$. Iron oxides contributed with $\sim 9 \%$, whereas $\mathrm{CaO}$ was less than $9 \%$, with the higher value in $\mathrm{FA}_{(\mathrm{SRF})}$ sample. However, both samples are regarded as low-calcium fly ashes of the F type according to ASTM [25]. The rest of the oxides contributed with values less than $4 \%$ in the descending order of $\mathrm{MgO}>\mathrm{K}_{2} \mathrm{O}>\mathrm{Na}_{2} \mathrm{O}>$ $\mathrm{SO}_{3}>\mathrm{P}_{2} \mathrm{O}_{5}>\mathrm{TiO}_{2}>\mathrm{BaO}>\mathrm{SrO}$. Comparing the two samples, $\mathrm{FA}_{(\mathrm{SRF})}$ showed to be more enriched in $\mathrm{Ca}, \mathrm{Mg}, \mathrm{S}, \mathrm{Ti}$, and $\mathrm{Na}$ than the $\mathrm{FA}_{(\mathrm{HC})}$ sample, although the differences were minor, apart the case of sulfur.

Table 2. Geochemical data of the studied fly ashes [23].

\begin{tabular}{|c|c|c|c|c|c|}
\hline Parameter & $\mathbf{F A}_{(\mathrm{HC})}$ & $\mathbf{F A}_{(\mathrm{SRF})}$ & & $\mathbf{F A}_{(\mathbf{H C})}$ & FA $_{(\text {SRF })}$ \\
\hline UC-R (wt. \% db) ${ }^{1}$ & 29.73 & 33.38 & & & \\
\hline Oxides wt. $\%$ & & & \multicolumn{3}{|c|}{ Trace Elements (mg/kg) } \\
\hline $\mathrm{SiO}_{2}$ & 45.14 & 44.91 & As & 42 & 25 \\
\hline $\mathrm{TiO}_{2}$ & 1.16 & 1.50 & $\mathrm{Cd}$ & 3 & 5 \\
\hline $\mathrm{Al}_{2} \mathrm{O}_{3}$ & 24.26 & 21.25 & Co & 66 & 118 \\
\hline $\mathrm{Fe}_{2} \mathrm{O}_{3}$ & 9.53 & 8.95 & $\mathrm{Cr}$ & 148 & 143 \\
\hline MgO & 3.71 & 4.31 & $\mathrm{Cu}$ & 321 & 356 \\
\hline $\mathrm{CaO}$ & 6.76 & 9.07 & Mn & 697 & 560 \\
\hline $\mathrm{Na}_{2} \mathrm{O}$ & 1.76 & 2.46 & $\mathrm{Ni}$ & 205 & 215 \\
\hline $\mathrm{K}_{2} \mathrm{O}$ & 2.84 & 2.32 & $\mathrm{~Pb}$ & 154 & 128 \\
\hline $\mathrm{P}_{2} \mathrm{O}_{5}$ & 1.72 & 1.29 & $\mathrm{Sb}$ & 37 & 169 \\
\hline \multirow[t]{2}{*}{$\mathrm{SrO}$} & 0.29 & 0.20 & V & 371 & 353 \\
\hline & & & $\mathrm{Hg}$ & 3 & 3 \\
\hline $\mathrm{BaO}$ & 0.45 & 0.35 & & & \\
\hline $\mathrm{SO}_{3}$ & 1.27 & 2.03 & & & \\
\hline
\end{tabular}

${ }^{1}$ UC-R: Un-combustible carbon-rich residual phases, determined as loss at $815^{\circ} \mathrm{C}$.

Regarding the potential hazardous trace elements, in both samples, $\mathrm{Mn}, \mathrm{V}, \mathrm{Ni}, \mathrm{Pb}$, and $\mathrm{Cr}$ displayed values above $100 \mathrm{mg} / \mathrm{kg}$; As displayed values below $50 \mathrm{mg} / \mathrm{kg}$; $\mathrm{Cd}$ and $\mathrm{Hg}$ displayed values below $5 \mathrm{mg} / \mathrm{kg}$; and $\mathrm{Co}$ and Sb showed a significant enrichment in the FA(SRF) sample (Table 2, Figure 1).

The evaluation of the X-ray diffraction data (Figure 2 and Table 3) indicates almost identical mineralogical features for both samples. Silicates in the form of quartz and mullite were predominant, constituting almost $80 \%$ of the crystalline phases, with the secondary occurrence of anhydrite and hematite and minor occurrence of apatite and traces of anatase. This mineralogical assemblage coincides with the distribution of major oxides: $\mathrm{Si}$ is part of quartz and mullite, $\mathrm{Al}$ of mullite, and $\mathrm{Fe}$ of hematite, whereas $\mathrm{Ca}$ and $\mathrm{S}$ are forming anhydrite and $\mathrm{Ca}$ and $\mathrm{P}$ apatite. 


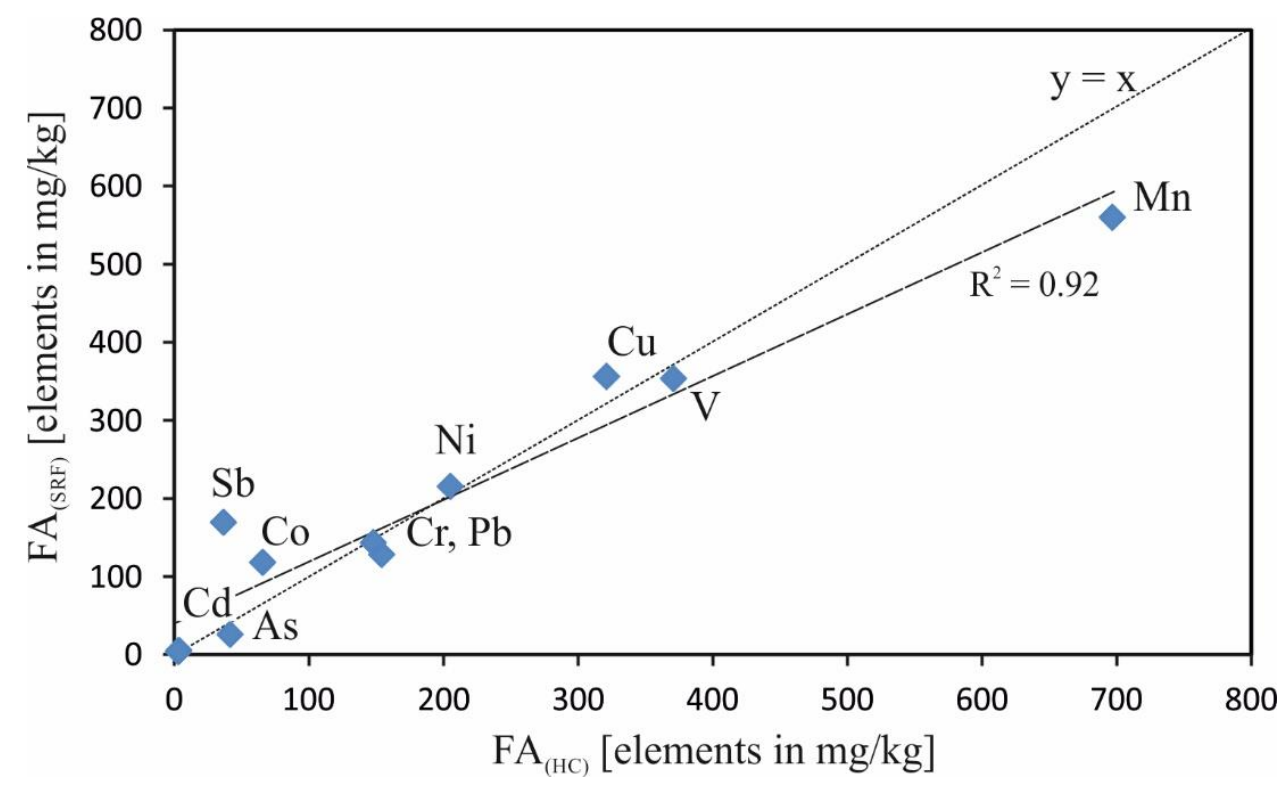

Figure 1. Correlation of trace elements in the studied fly ash samples.

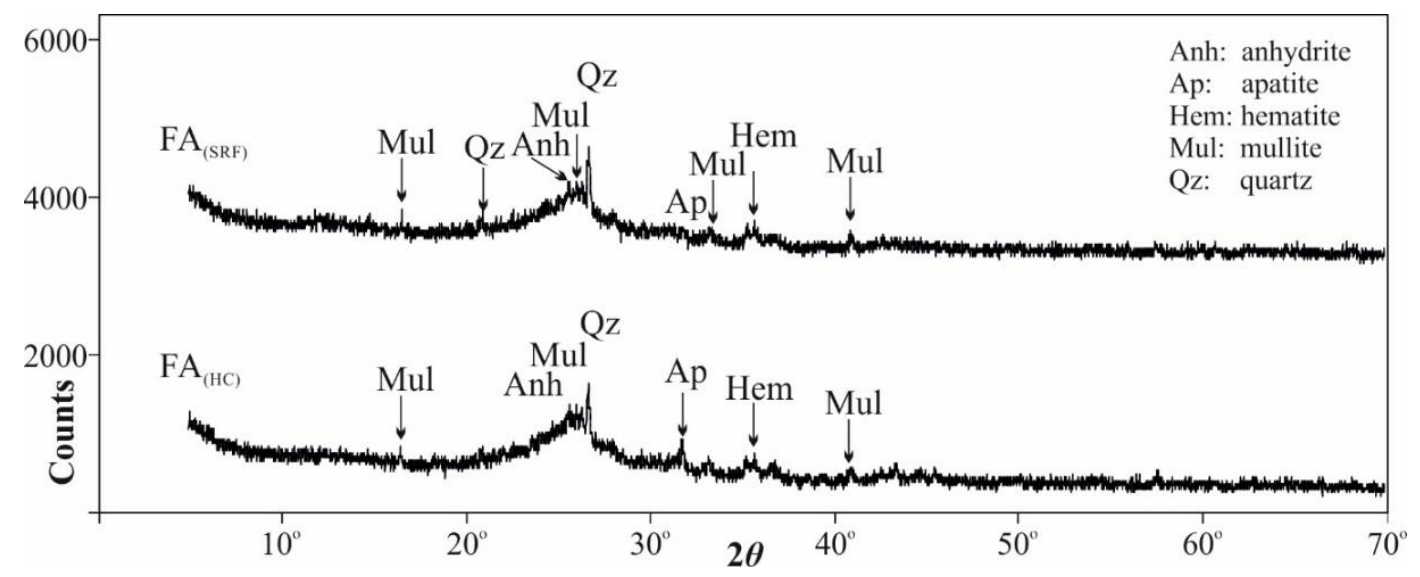

Figure 2. X-ray diffractograms of the studied fly ash samples.

Table 3. Quantitative mineralogical data of the studied fly ashes (in \% of crystalline phases).

\begin{tabular}{ccccccc}
\hline Sample & Quartz & Mullite & Anhydrite & Hematite & Apatite & Anatase \\
\hline & $\mathrm{SiO}_{2}$ & $\mathrm{Al}_{6} \mathrm{Si}_{2} \mathrm{O}_{13}$ & $\mathrm{CaSO}_{4}$ & $\mathrm{Fe}_{2} \mathrm{O}_{3}$ & $\mathrm{Ca}_{5}\left(\mathrm{PO}_{4}\right)_{3}$ & $\mathrm{TiO}_{2}$ \\
\hline $\mathrm{FA}_{(\mathrm{HC})}$ & 50 & 28 & 10 & 10 & 2 & $<1$ \\
$\mathrm{FA}_{(\mathrm{SRF})}$ & 51 & 27 & 12 & 8 & 2 & $<1$ \\
\hline
\end{tabular}

The identified mineralogical assemblages are typical for fly ashes originating from silicates-rich coals, e.g., $[3,7,26,27]$. Hence, it is reasonable to assume that the minerals in the fly ashes reflect mostly the paragenesis occurring in the feed coal, since the SRF material is predominantly of organic origin. Nevertheless, it seems that SRF provided additional Ca and $\mathrm{S}$, since anhydrite shows a small enrichment in the FA(SRF), being in agreement with the trend revealed from the geochemical data.

\subsection{Organic Petrographical Featues}

The maceral analysis of the coal used as a primary fuel shows that vitrinite was the predominant maceral group ( $72 \mathrm{vol} . \%-\mathrm{mmf}$ ), with subordinate occurrence of inertinite 
(25 vol.\%-mmf) and limited liptinite ( 3 vol.\%-mmf) groups. The petrographical study of the fly ash samples (Table 4) indicates the occurrence of a variety of organic-derived particles and mineral mater. Typically, partially or completely fused organic char particles, deriving from vitrinite and inertinite macerals as well as from the SRF compounds, can be traced in an admixture texture. In terms of the nature of the observed particles in both samples, the unburned C-residues exhibited higher content than the inorganic particles, with organic particles constituting $55 \%$ and $70 \%$ of the counted particles in $\mathrm{FA}_{(\mathrm{HC})}$ and $\mathrm{FA}_{(\mathrm{SRF})}$, respectively (Table 4). The $\mathrm{FA}_{(\mathrm{HC})}$ contained more inorganic particles than $\mathrm{FA}_{(\mathrm{SRF})}$, what was expected in terms of combustion efficiency. The inorganic mineral particles were mostly nonmetallic for both samples in the form of $\mathrm{Si}-\mathrm{Al}$ glass and cenospheres, coinciding with the silicate-rich mineral mode that the X-ray diffraction provided (Figure 3). Additional ferrospheres and magnesiaspheres based on the classification by Valentim et al. [3] also occurred. It is worth noting the $\mathrm{FA}_{(\mathrm{SRF})}$ displayed higher content of Al-rich mineral grains, with irregular shapes disseminated within the fine sooty matrix often.

Table 4. Quantitative petrographical characterization of fly ash organic components (based on [21]).

\begin{tabular}{|c|c|c|c|c|c|c|}
\hline \multirow[b]{2}{*}{ Samples } & \multicolumn{4}{|c|}{ Nature (vol.\%-wr ${ }^{1}$ ) } & \multicolumn{2}{|c|}{ Optical Character (vol.\%-mmf) } \\
\hline & Metallic & $\begin{array}{l}\text { Inorganic } \\
\text { Non-Metallic }\end{array}$ & Total & Organic & Fused & Unfused \\
\hline $\mathrm{FA}_{(\mathrm{HC})}$ & 2.2 & 43.0 & 45.2 & 54.8 & 88.7 & 11.3 \\
\hline $\mathrm{FA}_{(\mathrm{SRF})}$ & 2.7 & 27.5 & 30.2 & 69.8 & 82.1 & 17.9 \\
\hline \multirow[t]{2}{*}{ Samples } & \multicolumn{2}{|c|}{ Structure/Morphology (vol.\%-mmf) } & \multicolumn{2}{|c|}{ Optical Texture (vol.\%-mmf) } & \multicolumn{2}{|c|}{ Origin (vol.\%-wr) } \\
\hline & Dense & Porous & Isotropic & Anisotropic & Coal & Other Fuels \\
\hline $\mathrm{FA}_{(\mathrm{HC})}$ & 65.9 & 34.1 & 13.9 & 86.1 & 54.8 & - \\
\hline $\mathrm{FA}_{(\mathrm{SRF})}$ & 60.7 & 39.3 & 28.7 & 71.3 & 50.2 & 19.6 \\
\hline
\end{tabular}

1. wr: Whole rock basis; mmf: On mineral-free basis.
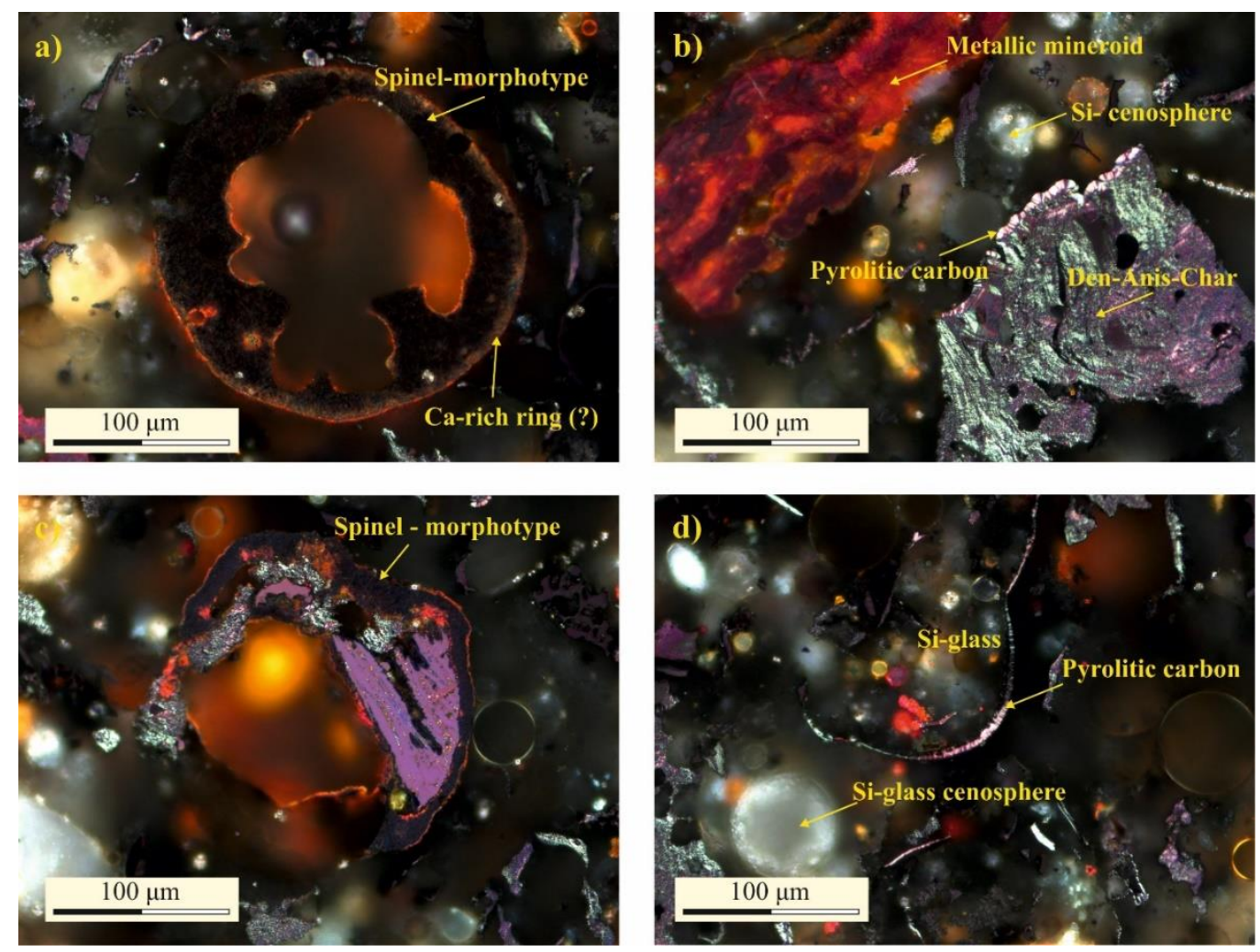

Figure 3. Photomicrographs (a-d) of various mineroid morphotypes in the $\mathrm{FA}_{(\mathrm{HC})}$ sample. 
The higher content of residual un-combustible organic matter obtained from petrographical observation than from the thermogravimetric method (Table 2) is explained by the different resolution of the techniques. Using petrography, a bias toward counting particulate matter $(>1-3 \mu \mathrm{m})$ is inherent, whereas bulk techniques such as thermogravimetry provide information for the whole-matrix, regardless of the particle size.

Nevertheless, the observation indicated a significant amount of un-combustible organic remnants, probably due to the low efficiency of the applied industrial combustion method. More specifically, Wasielewski et al. [28] previously noticed that during the co-combustion of coal and SRF in the WR-25 stocker boiler, the flue gases remained for only a limited time $(1.3 \mathrm{~s}$ instead of $2 \mathrm{~s}$, which is the legislative requirements specified for thermal processing of waste) in high temperatures $\left(>850^{\circ} \mathrm{C}\right)$, which did not allow a more efficient combustion. This lower combustion efficiency also caused the elevated content of sooty particles in $\mathrm{FA}_{(\mathrm{SRF})}$, since soot requires higher temperatures to combust totally. The admixture of wastes was only $10 \%$, hence the differences are not spectacular. Nevertheless, the differences are still evident. These issues result in increase of un-combustibles content and nature of organic char of the fly ash.

In terms of the organic particles, the microscopic examination revealed similar variation among the various levels of classification, with both fly ashes containing mostly fused ( $>80 \mathrm{vol} . \%-$ $\mathrm{mmf}$ ), dense (>60 vol.\%-mmf), and anisotropic solid C-residues (>70 vol.\%-mmf, Table 4).

However, some notable differences among the two fly ashes were observed that reflect the performance of the feed fuel during combustion and combustion dynamics. The $\mathrm{FA}_{(\mathrm{HC})}$ sample displayed higher contents of fused, dense, and anisotropic particulate C-residues than the $\mathrm{FA}_{(\mathrm{SRF})}$ sample (Figures 4 and 5), because of the high molecular ordering of coal, which can create anisotropic char in high temperatures. These features indicate that quite a significant part of the unburned C-residues (i.e., highly anisotropic particles) resembled a coal-derived coke-texture, meaning that part of the vitrinite grains escaped with flue gasses from combustion chamber as pyrolyzed and not yet combusted particles $[1,13,27,29]$. On the contrary, the isotropic fraction originated from the inertinite particles of the raw coal-feed.

The $\mathrm{FA}_{(\mathrm{SRF})}$ sample was characterized with higher content of unfused, porous isotropic chars, which can be explained by the morphology of the SRF component and its low molecular arrangement. The SRF were not able to create fused anisotropic char. It was also observed that $\mathrm{FA}_{(\mathrm{SRF})}$ contained more sooty organics in comparison to the $\mathrm{FA}_{(\mathrm{HC})}$ sample, which was probably the result of the lower combustion temperature and rubber component in the SRF.

The observed differences lead to the conclusion that the addition of SRF resulted in an increase of unfused, porous, and isotropic C-residues. The organic petrographical study also reveals that the $\mathrm{FA}_{(\mathrm{SRF})}$ was more enriched in $\mathrm{C}$-residues forms than expected from the initial blending proportion of $10 \% \mathrm{SRF}$. The results show that the ratio of coal-derived C-residues versus SRF C-residues was 70/30, suggesting that the combustion of SRF was less efficient than the coal.

Apart from the quantitative variations, there were also qualitative differences between similar forms of C-residues among the two fly ashes. The $\mathrm{FA}_{(\mathrm{HC})}$ was characterized by particles with more regular shapes (e.g., spherical) than the particles of the $\mathrm{FA}_{(\mathrm{SRF})}$ sample, which were usually angular with frayed edges. Additionally, fine sooty carbon was more evident in $\mathrm{FA}_{(\mathrm{SRF})}$, probably representing rubber-residual, covering the surfaces of larger particles. 

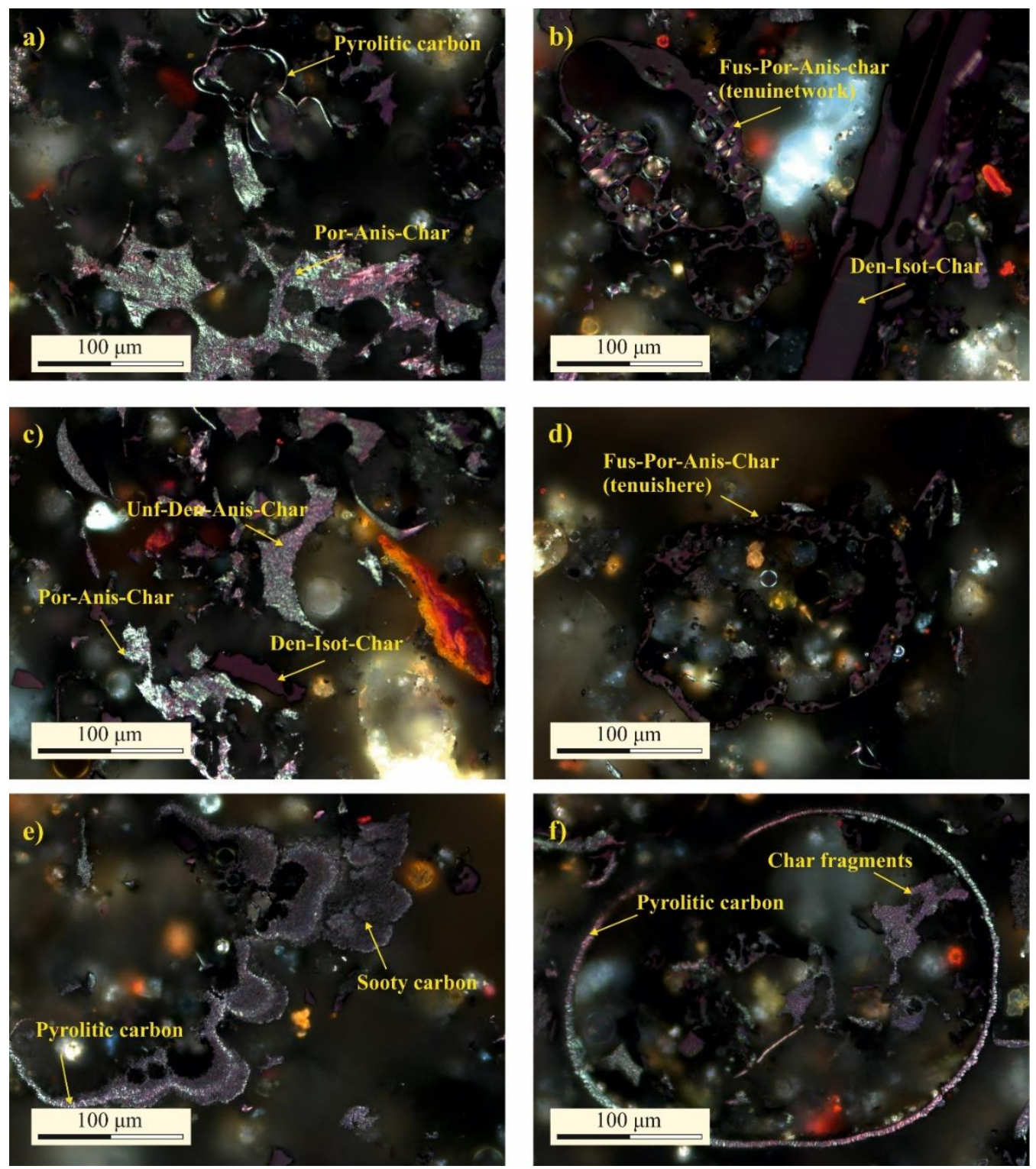

Figure 4. Exemplary photomicrographs $(\mathbf{a}-\mathbf{f})$ of char particles in $\mathrm{FA}_{(\mathrm{HC})}$ sample. (Fus: Fused; Unf: Unfused; Por: Porous; Den: Dense; Isot: Isotropic; Anis: Anisotropic).

The overall outcome of this study shows that the organic petrographical features of fly ashes originating either from combustion of solely coal or in conjunction to other fuels, along with the mineralogical and geochemical data, can depict the nature of the fly ashes in detail, as well as provide useful insights regarding the combustion process.

Additionally, the obtained results show that the studied fly ashes do not meet the requirements for utilization in the cement industry, as the unburned organic residuals are elevated [5,7]. Nevertheless, other applications, in which high content of organic matter either in an un-combustible or partially carbonized form is favorable, can be further investigated, such as implementation as soil-improving agencies, e.g., [30,31], or even in the environmental sector $[32,33]$. 

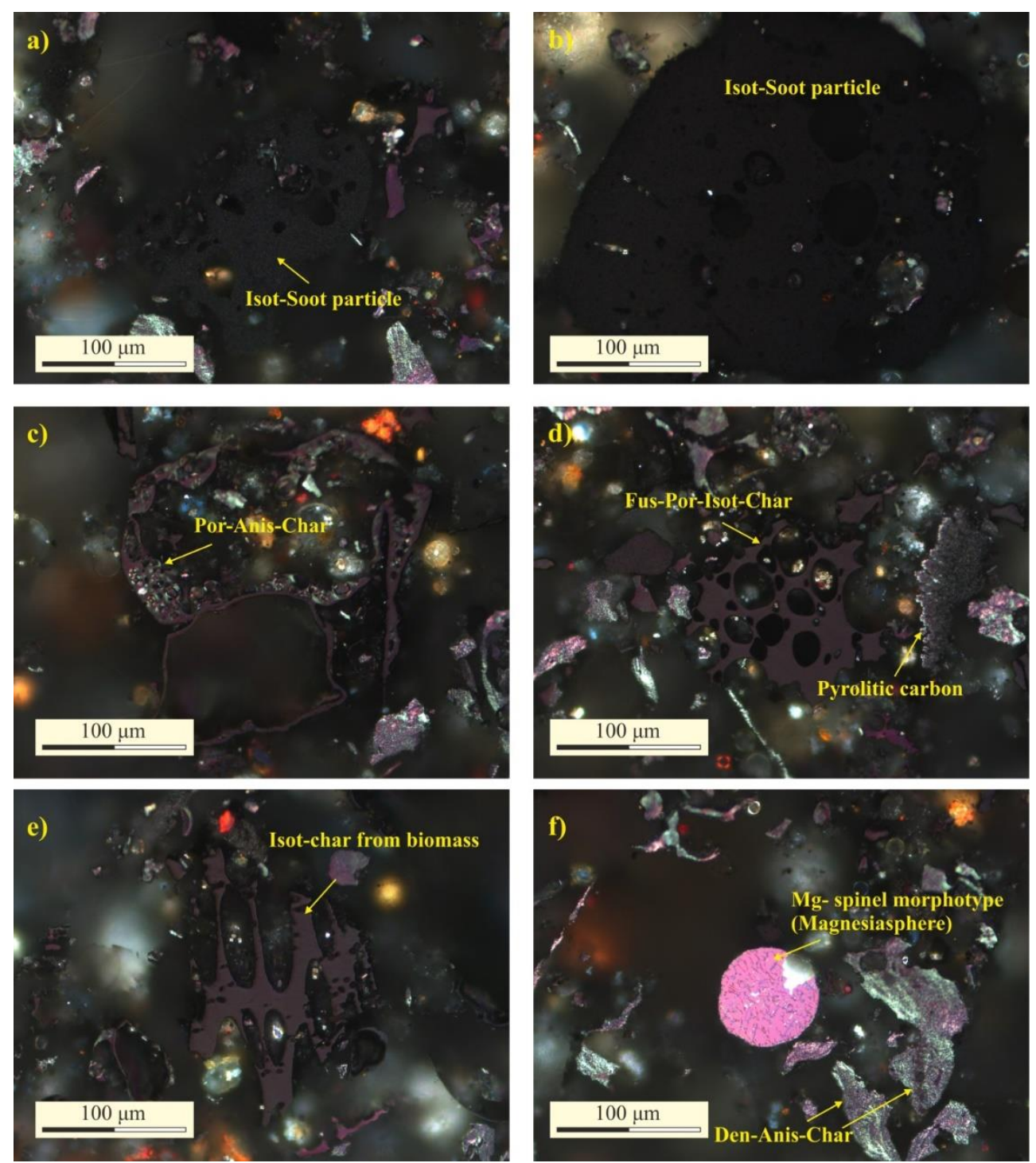

Figure 5. Exemplary photomicrographs (a-f) of the char particles in the $\mathrm{FA}_{(\mathrm{SRF})}$ sample. (Fus: fused; Unf: unfused; Por: porous; Den: dense; Isot: isotropic; Anis: anisotropic).

\section{Conclusions}

Organic petrographical studies according to ICCP guidelines and norms enable an in-depth characterization of fly ashes. The results of microscopic examination can provide valuable insights regarding the features of the feed fuels, answer questions concerning the combustion conditions, and explain different properties of given solid residues. Microscopic analysis is also a proper technique to classify fly ash for further utilization, particularly in the cases of coal and other wastes co-combustion.

The study of fly ash from the co-combustion of $90 \%$ high volatile bituminous coal and $10 \%$ SRF reveals that the inorganic mineral characteristics are almost similar to the fly ash produced from pure coal combustion. Si-Al phases (quartz, mullite), anhydrite, and hematite are the predominant phases.

The elementary features, however, are different, and in the studied case, an enrichment in $\mathrm{S}, \mathrm{Co}$, and $\mathrm{Sb}$ was revealed, indicating the enrichment mode of these elements in the feed SRF.

However, significant differences were observed regarding the features of the Cresiduals. Fly ash from the bituminous coal combustion was characterized by the presence of fused, dense, and anisotropic particulate C-residues, as expected. The fly ash from the 
coal-SRF co-combustion provided elevated contents of unfused, porous isotropic chars, and sooty particles due to the lower molecular arrangement of SRF and the presence of rubber, respectively.

The obtained characterization results of the fly ashes can be used as a base study for further investigation of the potential application of these materials as geopolymers. Although the high amount of unburned carbon forms prevents an optimum utilization in cement industry, other emerging applications should be explored, such as application as soil amendment in the agricultural sector.

Author Contributions: Conceptualization, M.W. and S.K.; methodology, M.W.; software, M.W.; validation, M.W., R.W. and S.K.; formal analysis, M.W.; investigation, M.W. and S.K.; resources, R.W. and S.K.; data curation, M.W.; writing—original draft preparation, M.W.; writing—review and editing, S.K. and R.W; visualization, M.W.; supervision, M.W.; funding acquisition, R.W. All authors have read and agreed to the published version of the manuscript.

Funding: The investigations in this paper were performed under research project no. GEKON/O5/26 $8002 / 17 / 2015$, which was financed by the National Centre for Research and Development and the National Fund for Environmental Protection and Water Management: "EkoRDF-innovation technology of alternative fuel generation from municipal waste for power plants and CHP plantskey element of the waste management system in Poland". The results presented in this paper were obtained during the research project entitled: Alternative fuels market in Poland-production and use for energy purposes (IChPW No 11.19.005.001.001) financed by the Ministry of Science and Higher Education.

Data Availability Statement: The data presented in this study are available within the article.

Conflicts of Interest: The authors declare no conflict of interest. The funders had no role in the design of the study; in the collection, analyses, or interpretation of data; in the writing of the manuscript, or in the decision to publish the results.

\section{References}

1. Hower, J.C. Petrographic examination of coal-combustion fly ash. Int. J. Coal Geol. 2012, 92, 90-97. [CrossRef]

2. Hower, J.C.; Groppo, J.G.; Graham, U.M.; Ward, C.R.; Kostova, I.J.; Maroto-Valer, M.M.; Dai, S. Coal-derived unburned carbons in fly ash: A review. Int. J. Coal Geol. 2017, 179, 11-27. [CrossRef]

3. Valentim, B.; Białecka, B.; Gonçalves, P.A.; Guedes, A.; Guimarães, R.; Cruceru, M.; Całus-Moszko, J.; Popescu, L.G.; Predeanu, G.; Santos, A.C. Undifferentiated Inorganics in Coal Fly Ash and Bottom Ash: Calcispheres, Magnesiacalcispheres, and Magnesiaspheres. Minerals 2018, 8, 140. [CrossRef]

4. Wawer, M. Identification of Technogenic Magnetic Particles and Forms of Occurrence of Potentially Toxic Elements Present in Fly Ashes and Soil. Minerals 2020, 10, 1066. [CrossRef]

5. Papadakis, V.G. Effect of sly ash on Portland cement systems. Part I: Low-calcium fly ash. Cem. Concr. Res. 1999, 29, 1727-1736. [CrossRef]

6. Chindaprasirt, P.; Jaturapitakkul, C.; Sinsiri, T. Effect of fly ash fineness on comprehensive strength and pore size of blended cement paste. Cem. Concr. Compos. 2005, 27, 425-428. [CrossRef]

7. Diaz, E.I.; Allouche, E.N.; Eklund, S. Factors affecting the suitability of fly ash as source material for geopolymers. Fuel 2010, 89, 992-996. [CrossRef]

8. Longos, A., Jr.; Tigue, A.A.; Dollente, I.J.; Malenab, R.A.; Bernardo-Arugay, I.; Hinode, H.; Kurniawan, W.; Promentilla, M.A. Optimization of the Mix Formulation of Geopolymer Using Nickel-Laterite Mine Waste and Coal Fly Ash. Minerals 2020, 10, 1144. [CrossRef]

9. Dwivedi, A.; Jain, M.K. Fly ash-Waste management and overview: A review. Recent Res. Sci. Technol. 2014, 6, 30-35.

10. Juenger, M.C.G.; Siddique, R. Recent advances in understanding the role of supplementary cementitious materials in concrete. Cem. Concr. Res. 2017, 78, 71-80. [CrossRef]

11. Uliasz-Bocheńczyk, A.; Mokrzycki, E. The potential of FBC fly ashes to reduce $\mathrm{CO}_{2}$ emissions. Sci. Rep. 2020, 10, 9469. [CrossRef] [PubMed]

12. EIA. Energy Information. Available online: https://www.eia.gov/international/analysis/country/POL (accessed on 15 December 2020).

13. Wójcik, M.; Stachowicz, F.; Masłoń, A. The possibility of the application of fly ashes in order to the improvement of sewage sludge dewatering. J. Civ. Eng. Environ. Archit. 2017, 34, 377-393. (In Polish) [CrossRef]

14. Blajer, M.; Stopkowicz, A.; Adamczyk, J.; Cała, M. The preliminary research of the physico-mechanical properties of aggregates based on the colliery shale, supplemented by fly ash. Arch. Min. Sci. 2019, 64, 21-34. 
15. Korniejenko, K.; Halyag, N.P.; Mucsi, G. Fly ash as a raw material for geopolymerisation—Chemical composition and physical properties. IOP Conf. Ser. Mater. Sci. Eng. 2019, 706, 012002. [CrossRef]

16. Suárez-Ruiz, I.; Ward, C. Coal Combustion. In Applied Coal Petrology, the Role of Petrology in Coal Utilization, 1st ed.; Suárez-Ruiz, I., Crelling, J.C., Eds.; Academic Press: London, UK, 2008.

17. Ahmaruzzaman, M. A review on the utilization of fly ash. Prog. Energy Combust. Sci. 2010, 36, 327-363. [CrossRef]

18. Jarosiński, A. Mineral and Chemical Composition of Fly Ashes Deriving from Co-Combustion of Biomass with Coal and Its Application. Inżynieria Miner. J. Pol. Miner. Eng. Soc. 2013, 14, 141-148.

19. Hower, J.C.; Mastalerz, M. An approach toward a combined scheme for the petrographic classification of fly ash. Energy Fuels 2001, 15, 1319-1321. [CrossRef]

20. Hower, J.C.; Suárez-Ruiz, I.; Mastalerz, M. An approach toward a combined scheme for the petrographic classification of fly ash: Revision and clarification. Energy Fuels 2005, 19, 653-655. [CrossRef]

21. Suárez-Ruiz, I.; Valentim, B.; Borrego, A.G.; Bouzinos, A.; Flores, D.; Kalaitzidis, S.; Malinconico, M.L.; Marques, M.; MiszKenan, M.; Predeanu, G.; et al. Development of a petrographic classification of fly ash components from coal combustion and co-combustion. (An ICCP Classification System, Fly Ash Working Group-Commission III). Int. J. Coal Geol. 2017, 183, 188-203.

22. Iacovidou, E.; Hahladakis, J.; Deans, I.; Velis, C.; Purnell, P. Technical properties of biomass and solid recovered fuel (SRF) co-fired with coal: Impact on multi-dimensional resource recovery value. Waste Manag. 2018, 73, 535-545. [CrossRef]

23. Wasielewski, R.; Wojtaszek, M.; Plis, A. Investigation of fly ash from co-combustion of alternative fuel (SRF) with hard coal in a stoker boiler. Arch. Environ. Prot. 2020, 46, 58-67.

24. ISO (International Organization for Standardization) 7404-2. Methods for The Petrographic Analysis of Coals-Part 2: Methods of Preparing Coal Samples; International Organization for Standardization: Geneva, Switzerland, 2009; 12p.

25. ASTM C618-19. Standard Specification for Coal Fly Ash and Raw or Calcined Natural Pozzolan for Use in Concrete; ASTM International: West Conshohocken, PA, USA, 2019.

26. Williams, R.P.; van Riessen, A. Determination of the reactive component of fly ashes for geopolymer production using XRF and XRD. Fuel 2010, 89, 2683-3692. [CrossRef]

27. Lester, E.; Alvarez, D.; Borrego, A.G.; Valentim, B.; Flores, D.; Clift, D.A.; Rosenberg, P.; Kwiecinska, B.; Barranco, R.; Petersen, H.I.; et al. The procedure used to develop a coal char classification-Commission III Combustion Working Group of the International Committee for Coal and Organic Petrology. Int. J. Coal Geol. 2010, 81, 333-342. [CrossRef]

28. Wasielewski, R.; Głód, K.; Telenga-Kopyczyńska, J. Energy and emission aspects of co-combustion solid recovered fuel with coal in a stoker boiler. E3S Web Conf. 2018, 28, 01037. [CrossRef]

29. Lester, E.; Cloke, M.; Allen, M. Char characterization using image analysis techniques. Energy Fuels 1996, 10, 696-703. [CrossRef]

30. Jarosz-Krzemińska, E.; Poluszyńska, J. Repurposing fly ash derived from biomass combustion in fluidized bed boilers in large energy power plants as a mineral soil amendment. Energies 2020, 13, 4805. [CrossRef]

31. Ewa Szatyłowicza, E.; Krasowska, M. Assessment of heavy metals leaching from fly ashes as an indicator of their agricultural use. Desalin. Water Treat. 2020, 199, 288-296. [CrossRef]

32. Karapanagioti, H.; James, G.; Sabatini, D.; Kalaitzidis, S.; Christanis, K.; Gustafsson, O. Evaluating Charcoal presence in sediments and its effect on Phenanthrene sorption. Water Air Soil Pollut. Focus 2004, 4, 359-373. [CrossRef]

33. Cornelissen, G.; Breedveld, G.D.; Kalaitzidis, S.; Christanis, K.; Kibsgaard, A.; Oen, A. Strong sorption of native PAH's to pyrogenic and unburned carbonaceous geosorbents in sediments. Environ. Sci. Technol. 2006, 40, 1197-1203. [CrossRef] 